\title{
TIMP4 wt Allele
}

National Cancer Institute

\section{Source}

National Cancer Institute. TIMP4 wt Allele. NCI Thesaurus. Code C124087.

Human TIMP4 wild-type allele is located in the vicinity of 3p25 and is approximately $6 \mathrm{~kb}$ in length. This allele, which encodes metalloproteinase inhibitor 4 protein, is involved in the regulation of extracellular matrix degradation. 